\title{
The Impact of E-Service Quality and E-Loyalty on Online Shopping: Moderating Effect of E-Satisfaction and E-Trust
}

\author{
Rami Mohammad Al-dweeri ${ }^{1}$, Zaid Mohammad Obeidat ${ }^{1}$, Mohammad Ahmad Al-dwiry ${ }^{2}$, Muhammad Turki \\ Alshurideh $^{1}$ \& Alaa Mohammad Alhorani ${ }^{2}$ \\ ${ }^{1}$ The School of Business, The University of Jordan, Amman, Jordan \\ 2 Business School, Al ahliyya Amman University, Amman, Jordan \\ Correspondent: Rami Mohammad Al-dweeri, The School of Business, The University of Jordan, Amman, Jordan. \\ E-mail: r.dweeri@ju.edu.jo
}

Received: December 26, 2016

Accepted: February 11, 2017 Online Published: March 2, 2017

doi:10.5539/ijms.v9n2p92

URL: http://doi.org/10.5539/ijms.v9n2p92

\begin{abstract}
This paper analyzes the role of online satisfaction and e-trust as mediators in the relationship between electronic service quality (e-SQ) and online loyalty (integrating behavioral and attitudinal elements), in the context of e-shopping. In an increasingly competitive environment, e-retailers need to know the determinants of the success of their online distribution channels in terms of service quality and the influence of this on e-satisfaction, e-trust and e-loyalty. Using a sample of 302 website users of amazon.com in Jordan, confirmatory factor analysis and structural equation modeling were performed to test the relationship between these dimensions. Three dimensions were found to be the main explanatory factors of e-SQ, namely efficiency, privacy and customer service. In addition, it was confirmed that satisfaction mediates the relationship between e-SQ and behavioral and attitudinal loyalty.
\end{abstract}

Keywords: electronic services quality, e-satisfaction, e-trust, behavioral loyalty, attitudinal loyalty

\section{Introduction}

The relationships between service quality, customer satisfaction, trust and loyalty are well documented in the services literature (Parasuraman, Zeithaml, \& Berry, 1988). Moreover, the way in which electronic service quality (e-SQ) positively influences online businesses success has been established in the literature (Yang \& Fang, 2004; Zeithaml, Parasuraman, \& Malhotra, 2002). This relationship often leads to customer purchase intentions (Aladwani, 2006), customer satisfaction (Kim \& Stoel, 2004), website brand equity (Tsao \& Tseng, 2011) and online loyalty (Flavián, Guinalíu, \& Gurrea, 2006; Gounaris, Dimitriadis, \& Stathakopoulos, 2010; Gronholdt, Martensen, \& Kristensen, 2000; Marimon, Petnji, \& Casadesus, 2012).

In addition, the literature focuses on the relationships that exist between service quality and perceived value, and the impact of these on customer satisfaction, corporate image, and behavioral intentions (Al Dmour, Alshurideh, \& Shishan, 2014; Wu, 2014; Hu, Kandampully, \& Juwaheer, 2009; Cronin, Brady, \& Hult, 2000).

However, despite the insights provided by these studies, no specific studies on the dimensions of e-SQ and the consequences of these for the online shopping sector yet exist (Kassim \& Abdullah, 2010; Jin, Yong, \& Kim, 2008; Anderson \& Srinivasan, 2003). As a result, the set of relations between the four important elements for the success of e-services (e-SQ, e-satisfaction, e-trust, and e-loyalty) is also not yet clear. This work contributes to the e-services literature by clarifying the relationship between these constructs. In this study, satisfaction is considered as a result of e-SQ, and it affects e-trust and e-loyalty, affecting behavioral loyalty first and attitudinal loyalty second. To the knowledge of the authors, this specific effort has not yet been undertaken, particularly in the context of e-services in the online shopping sector.

To carry out this study, a scale for measuring e-SQ, e-satisfaction, e-trust, and e-loyalty is proposed and validated. Second, a model of the relationships between the four constructs is designed and tested, and, in particular, we investigate whether e-SQ positively and directly affects online loyalty (behavioral or attitudinal), together with whether e-satisfaction and e-trust are mediating variables in this relationship. 


\section{Literature Review}

\subsection{Electronic Service Quality}

E-services have been defined as services that are offered via the internet (Rust, 2001; Zeithaml, Parasuraman, \& Malhotra, 2002), are managed by customers (Ruyter, Wetzels, \& Kleijnen, 2001), and are interactive in nature (Fassnacht \& Koese, 2006). Initially, it was thought that a web presence and low prices for the items were the main factors ensuring success in e-services. Recently, issues related to e-SQ have been identified as the key elements (Parasuraman, Zeithaml, \& Malhotra, 2005; Zeithaml, Parasuraman, \& Malhotra, 2002). Previous research has highlighted the poor quality of service delivery over the internet (Ahmad, 2002; Cox \& Dale, 2002), and the need to modify previous e-SQ measures such as SERVQUAL, so that they better suit the context of a web-based service (Li, Tan, \& Xie, 2002). It is necessary to understand better how customers perceive and evaluate services (Zeithaml, Parasuraman, \& Malhotra, 2002), and to develop a strategy based on providing customers with high quality e-SQ. Following such a strategy, customers would feel satisfied with the service and their loyalty would be gained, as is the case with traditional services (Reichheld \& Schefter, 2000).

At present, there is no unanimous agreement in the literature on the concept of e-SQ. While some scholars have focused their studies on the quality of the website (e.g., Loiacono, Watson, \& Goodhue, 2002; Li et al., 2002), others have adopted a broader view, including contacts with personal agents for customer services (Yang, Peterson, \& Cai, 2003). The first stream is represented by Grönroos, Heinonen, Isoniemi, \& Lindholm (2000), who believe that e-SQ can be divided into a functional dimension (what is delivered as a result of the service) and a technical dimension (how the service process is delivered). This view has been echoed and expanded by other researchers (Bauer, Falk, \& Hammerschmidt, 2006; Parasuraman et al., 2005; Rust \& Lemon, 2001), who believe that a comprehensive definition of e-SQ should go beyond mere commercial transactions and take into account all the key events and interactions that occur before, during and after the delivery of e-services. In this view, e-SQ is the degree to which a website facilitates a purchase efficiently, meeting the needs and expectations of the customer and without creating problems (Gummerus, Liljander, Pura, \& Van Riel, 2004).

Generally, when looking at the e-SQ literature, two main research themes appear. The first stream of research in the E-SQ literature focuses on developing scales to measure e-SQ in a number of different contexts and dimensions. For example, in the library context, O’Niell, Wright, \& Fitz (2001) developed an online library service quality scale. In the tourism context, Ho \& Lee (2007) developed an E-travel service quality scale, and Cristóbal, Flavián, \& Guinalíu (2007) developed a scale to measure e-SQ for a tourism website. In the banking context, a scale to measure E-banking service quality was developed by Ibrahim et al. (2006). In the web context, a number of scholars (e.g., Aladwani \& Palvia, 2002; Barnes \& Vidgen, 2002; Bauer et al., 2006; Gounaris \& Dimitriadis, 2003; Swaid \& Wigand, 2009; Yang, Peterson, \& Cai, 2005) have developed scales to measure website service and portal quality. Moreover, in the retailing context, a number of scales to measure electronic retailing service quality have been developed by Yoo \& Donthu (2001), Collier \& Bienstock (2006), Wolfinbarger \& Gilly (2003).

The second stream of research in E-SQ literature focuses on the influence of E-SQ on a number of variables, and positive and significant links have been found between E-SQ and these variables. The variables include satisfaction (e.g., Zeglat, Shrafat, \& Al-Smadi, 2016), behavioral intentions and attitudes (e.g., Lien, Wen, \& Wu, 2011; Zeglat, Shrafat, \& Al-Smadi, 2016), trust (e.g., Beneke, Acton, Richardson, \& White, 2011), and loyalty (e.g., Chen, Kune, Tsai, Hsu, \& Lee, 2013; Cristóbal et al., 2007; Kassim \& Abdullah, 2010; Swaid \&Wigand, 2009; Prougestaporn, Visansakon, \& Saowapakpongchai, 2015; Wali \& Opara, 2012). However, despite the insights provided by these studies, limited research attention has been given to exploring this issue in a new context such as Jordan. In addition, none of the previous work has attempted to measure the influence of e-SQ on different types of loyalty (behavioral and attitudinal) through e-satisfaction and e-trust.

\subsection{Dimensions of E-SQ}

The first proposals for the description of e-SQ as a multidimensional construct, and for its measurement through a scale that adapts the dimensions of traditional service quality, were developed by Parasuraman et al. (2005), using the E-S-QUAL scale in the field of e-commerce. However, the characteristics that differentiate traditional service from e-service led to a necessary revision of the dimensions and items that make up the traditional scale. Consequently, numerous authors have developed new models for understanding and measuring e-SQ (WebQual (Loiacono, Watson, \& Goodhue, 2007), and eTransQual (Bauer et al., 2006), and have proposed a number of dimensions (efficiency, privacy/security, fulfilment/reliability, enjoyment, and customer service/communication).

Efficiency refers to the ability of a website to offer relevant information to help consumers obtain the products they desire with minimal effort (Zeithaml, Parasuraman, \& Malhotra, 2002), and consequently affects e-SQ. The 
efficiency dimension is broken down into several sub-dimensions: informational content and website updating (Li et al., 2002; Wolfinbarger \& Gilly, 2003), website design (Yen \& Lu, 2008), usability (Parasuraman et al., 2005), and navigation (Bauer et al., 2006). Swaid \& Wigand (2009) and Águila, Padilla, \& Al-dweeri (2013) confirmed that information has positive effects on e-satisfaction, while Herington \& Weaven (2007) noted that, although efficiency is found to be most important overall and is rated most highly by respondents, it has the least impact upon satisfaction. Efficiency has a positive impact on customer trust, however (Kao \& Lin, 2016; Kim, Jin, \& Swinney, 2009). Hansen \& Jonsson (2013) found that efficiency has no positive impact on e-trust. Thus, the following hypotheses are proposed:

H1.a: Efficiency is positively related to e-satisfaction.

\section{H1.b: Efficiency is positively related to e-trust.}

Furthermore, privacy/security is considered one of the most important aspects of e-SQ (Lee \& Lin, 2005; Parasuraman et al., 2005; Van Riel, Semeijn, \& Janssen, 2003). Generally, online customers cannot interact with the employees or physical facilities of the firm with which they deal (Reichheld \& Schefter, 2000), so it follows that trust must be established in other ways. In fact, among the factors that have prevented the more rapid development of electronic commerce, the most noteworthy is the lack of trust and the perceived insecurity of making or receiving payments over the internet (Bauer et al., 2006; Malhotra \& Segars, 2005). Some authors have found that privacy does not exert a significant influence on e-satisfaction (Cristóbal et al., 2007; Kim \& Stoel, 2004).

The results obtained by Kim et al. (2009) suggest that privacy is a driver of e-trust, which, in turn, leads to customer e-satisfaction. Ribbink, Van Riel, Liljander, \& Streukens (2004) also found that in an online environment privacy has a high impact on customer trust and even on establishing long-term relationships with customers (Alshurideh, Al Kurdi, Vij, Obiedat, \& Naser, 2016). Consequently, the following hypotheses are formulated:

H2.a: Privacy is positively related to e-satisfaction.

H2.b: Privacy is positively related to e-trust.

Customer service/communication refers to the ability of a site to maintain relationships with customers when problems arise in transactions. This is normally done by keeping channels of communication open with customers (Santos, 2003), providing assistance if problems arise (Wolfinbarger \& Gilly, 2003), and, consequently, adding value (Cox \& Dale, 2002). Customer service/communication also constitutes an important factor for e-SQ (Gounaris \& Dimitriadis, 2003). Wolfinbarger \& Gilly (2003) considered customer service to be the level of response or support and the desire to respond quickly to a customer when a question is asked. Cox \& Dale (2002) noted that customer service adds value to the customer experience and helps to build relationships with customers, with additional services and information being offered. According to these authors, it is possible to establish long-term customer relationships by offering a customized service, encouraging frequent purchases and offering services that add value. Lee \& Lin (2005) found customer service to affect e-satisfaction mildly. The following hypotheses are proposed:

H3.a: Customer service is positively related to online customer satisfaction.

H3.b: Customer service is positively related to online customer trust.

\subsection{E-satisfaction}

Satisfaction in the virtual environment (i.e., online satisfaction) has become an important topic of analysis, being a key factor in competing with rivals and achieving success in the market (Anderson \& Srinivasan, 2003; Cox \& Dale, 2001; Zeglat et al., 2016). However, it is a difficult concept to define, because of its numerous interactions with other variables. Nevertheless, it may be considered an affective attitude, influencing the user's behavior and assessment of the products/services, which in turn determines the user's fidelity (Zhang \& Dran, 2000). The determinants of the construct have been studied (Szymanski \& Hise, 2000), as have its relationships with e-SQ and online loyalty (Cyr, Kindra, \& Dash, 2008; Gounaris et al., 2010; McKinney, Yoon, \& Zahedi, 2002). The relationship between e-SQ and satisfaction, including information quality and customer expectation matching, has been modeled by a number of researchers (McKinney et al., 2002; Zeglat et al., 2016). Moreover, Hsu \& Hsu (2008), Shahabuddin (2014), and Zeglat et al. (2016) found that there were significant and positive correlations between service quality and both customer satisfaction and customer loyalty.

\subsection{E-trust}

The concept of trust is also one of the most important elements in the creation of long-term relationships with 
customers, especially in relation to maintaining the confidentiality of information relating to clients, and in relation to commitments to provide the best service/product over time. Trust is generally formed between an organization and its customers through: 1) efficiency, meaning competence in providing the service, and 2) attention customer interest (Singh \& Sirdeshmukh, 2000). Chu (2009) defines trust as a human characteristic that is based on the assessment of another's personality traits. There are several definitions of trust in the online environment, including that trust is a set of distinct beliefs in a person's integrity, benevolence, and ability (Gefen, Karahanna, \& Straub, 2003). According to McKinney, Yoon, \& Zahedi (2002), e-trust depends on the assurance of security, reputation, web searching, fulfillment (e.g., willingness to customize), presentation (e.g., web quality), technology, and interactions (e.g., e-forums). Kim et al. (2009) claimed that online retailers should realize that, in order to build e-loyalty and e-satisfaction, there has to be a prior development of e-trust. A study by Kao \& Lin (2016), which aimed to test whether relationships exist between trust and loyalty, suggested that loyalty has a positive relationship with trust, and that trust exerts a positive impact on loyalty. Some authors (Ribbink et al., 2004; Ghane, Fathian, \& Gholamian, 2011) have claimed that e-trust does not only have a direct impact on e-loyalty, but also has an indirect influence on e-loyalty through e-satisfaction. We assume that e-trust has an indirect influence on e-loyalty through e-satisfaction. Singh \& Sirdeshmukh (2000) have argued that in any buyer-seller relationship, the buyer's trust evaluations before a specific exchange episode have a direct influence on the buyer's post-purchase satisfaction. Additionally, previous studies have found e-trust to be a strong predictor of e-satisfaction (e.g., Al-Nasser, Yusoff, Islam, \& ALNasser, 2013; Kim et al., 2009).

\subsection{E-loyalty}

Online loyalty has parallels with the concept of loyalty to an establishment, in the sense that loyalty to an establishment generates purchase behavior and repeated visits to the store (Anderson \& Srinivasan, 2003; Gommans, Krishnan, \& Scheffold, 2001). To date there have been a number of papers that demonstrate how e-SQ influences online loyalty (Flavián et al., 2006; Srinivasan, Anderson, \& Ponnavolu, 2002; Prougestaporn, Visansakon, \& Saowapakpongchai, 2015). However, these studies do not distinguish between the two types of loyalty (attitudinal and behavioral). Attitudinal loyalty refers to a positive attitude that leads to repeated behavior (Soltani \& Gharbi, 2008) and is considered to be true loyalty. Behavioral loyalty refers to the customer's commitment to the brand, thus taking into account the emotional component that would incite customers to change supplier if the supplier changes its marketing strategy (Pitta, Franzak, \& Fowler, 2006). Thus, loyalty does not solely concern repurchasing behavior, and nor does it solely concern commitment, but it takes both factors together, by considering that loyalty also arises from a consumer's psychological involvement with the website, which results in a positive attitude and an effective repurchasing intention (Pritchard, Havitz, \& Howard, 1999). E-SQ has been found to influence trust and to explain the emotional loyalty of website visitors (Lynch, Kent, \& Srinivasan, 2001).

\subsection{Relationship between Online Satisfaction and Loyalty}

In services, the relationship between satisfaction and loyalty seems almost intuitive, and several researchers (e.g., Chen et al., 2013; Cronin \& Taylor, 1992; Prougestaporn, Visansakon, \& Saowapakpongchai, 2015; Woodside, Frey, \& Daly, 1989) have attempted to confirm this idea. Satisfaction affects a user's behavior and his or her assessment of the service, and this in turn affects loyalty (Zhang \& Dran, 2000). However, a few studies have addressed this relationship (between satisfaction and online loyalty) for e-services. For instance, Anderson \& Srinivasan (2003) considered that the impact of satisfaction on online loyalty is affected by several variables, such as trust and the e-commerce value received. This relation is stronger in virtual environments than in traditional ones (Shankar, Smith, \& Rangaswamy, 2003), and achieving loyalty in virtual environments is more difficult and costly than in the offline world (Van Riel, Liljander, \& Jurriens, 2001). Moreover, if online loyalty is to be achieved then e-SQ is required to meet the customer's expectations (Cristóbal et al., 2007). We can consider satisfaction to mediate between the other two concepts, given that if service quality is not satisfactory then the customers will have no loyalty. Moreover, using a development of the e-SERVQUAL scale for measuring the quality of service, Aladwani (2006) demonstrated a positive relationship between satisfaction and loyalty. Similarly, using the same scale, Dunn, Baloglu, Brewer, \& Qu (2009) demonstrated the relationship between the three constructs. Finally, applying the PeSQ model, Cristóbal et al. (2007) showed that e-SQ is an antecedent of satisfaction and that this in turn is an antecedent of loyalty. Additionally, Kassim \& Abdullah (2010) found a positive relationship between satisfaction and loyalty. This study therefore examines the relationship between e-satisfaction, e-trust, and the two aspects of loyalty (behavioral and attitudinal).

H4: e-satisfaction is positively related to e-trust.

H5.a: e-satisfaction is positively related to customer behavioral loyalty online. 
H5.b: e-satisfaction is positively related to customer attitudinal loyalty online.

H6.a: e-trust is positively related to customer behavioral loyalty online.

H6.b: e-trust is positively related to customer attitudinal loyalty online.

H7: Customer behavioral loyalty online is positively related to customer attitudinal loyalty.

As mentioned, this research aims, through empirical evidence, to elaborate on the identification of the most important aspects of e-SQ and, secondly, to identify the relation between the variables of online satisfaction and online loyalty. In addition, online loyalty is considered from two dimensions, namely behavioral and attitudinal loyalty. With regard to this objective and the literature review that is reported above, the research model was developed as shown below.

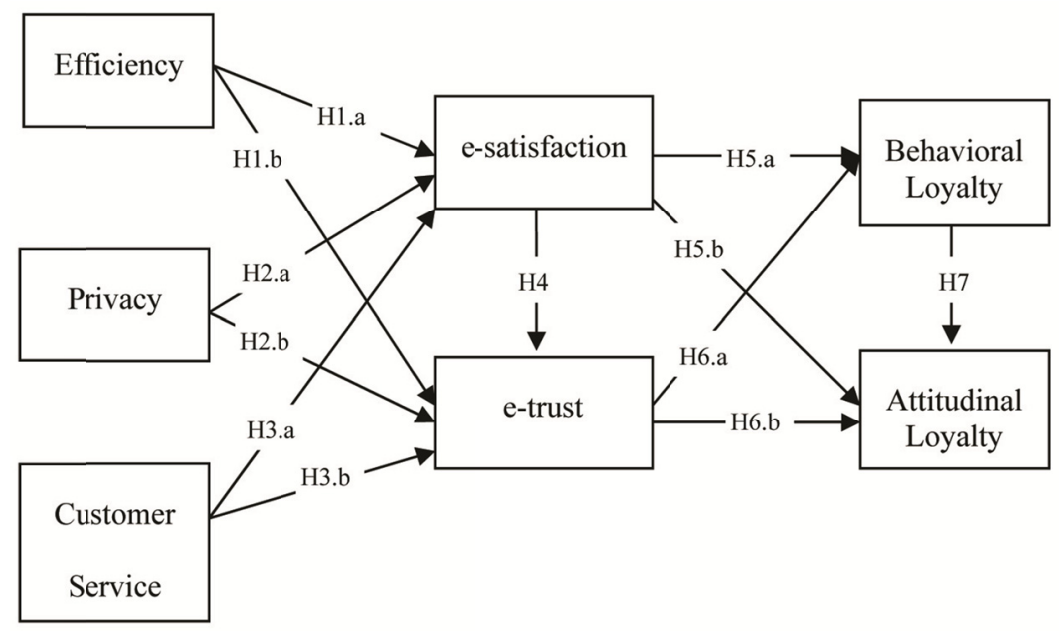

Figure 1. Proposed model

\section{Data and Estimation Results}

\subsection{Sample Characteristics}

A questionnaire was addressed to students at Jordan University who had previously used and purchased from amazon.com. We chose to use a student sample as in other studies (Lee \& Lin, 2005; Parasuraman et al., 2005), and because, in addition, students are the heaviest users of the internet (Obeidat, 2014). University students were considered appropriate for this study because they represent the first generation to grow up with the internet (Howard, Rainie, \& Jones, 2001). This generation is the major group participating in e-shopping, because university students form part of the adult population to whom the internet is easily accessible, and they use the internet as a matter of daily routine (Azam, Qiang, \& Abdullah, 2012).

We posted an online survey on the Jordan University Facebook page. The first question asked whether participants had ever made a purchase from amazon.com. If they answered no, a thank-you message was given and the questionnaire was closed. Initially, 29 items using a 5-point Likert scale were used, and the questionnaire was refined after a pre-test with two researchers. The final sample amounted to 302 valid questionnaires, similar to other e-SQ studies (273 in Kim \& Stoel (2004), 351 in Flavián et al. (2006), and 384 in Bauer et al. (2006)). Of the subjects who filled out the questionnaire, the majority $(61.9 \%)$ were female, $98.7 \%$ were less than 25 years old, $65.1 \%$ had purchased at least three times from Amazon, and more than half had visited the amazon.com website at least six times in the past 12 months. Furthermore, the analysis of variance carried out showed that there were no significant differences, which suggests that the sample is unbiased (Pallant, 2001).

\subsection{Measurement Validation}

Exploratory factor analysis was performed to test the construct validity. The KMO value was 0.948 , and Bartlett's spherical test showed a significant result, with $\chi^{2}=5125.879$, indicating the appropriateness of the factor analysis. Cronbach's $\alpha$ has a value for all variables higher than 0.7 (efficiency $=0.906$; privacy $=0.869$; customer service $=0.831$; e-satisfaction $=0.830$; e-trust $=0.761$; behavioral loyalty $=0.726$; attitudinal loyalty $=$ 0.746 ), indicating good reliability. 


\subsection{Model Estimation and Hypothesis Testing}

Figure 2 presents the structural equation modeling results specified in the AMOS 20.0 output. The results relating to the fit of the structural model generally show good fit. Table 1 provides a summary of the goodness-of-fit statistics. As can be seen, all the indices fall within the recommended ranges. The $\chi^{2}$ statistics for the model are 486.15, with 301 degrees of freedom. In particular, the relative $\chi^{2} /$ degrees of freedom value of 1.62 is less than the recommended maximum of 3.00 (Bagozzi, Yi, \& Nassen, 1998; Kline, 1998), which represents a good fit. The RMSEA value of 0.05 , which is below the recommended maximum of 0.08 suggested by Browne \& Cudeck (1993), also indicates that the model fits well, while the GFI value of 0.90 and the AGFI value of 0.87 are still acceptable because they are within the range of 0.80-0.90 recommended by Jöreskog \& Sörbom (1989). This research also used the IFI and CFI to measure the goodness-of-fit of the model, since the IFI and CFI are more appropriate to measure goodness-of-fit when the sample size is small (Byrne, 2001). In this study, the IFI (0.96) and CFI (0.96) index values for the measurement model both exceed the recommended level of 0.90 (Byrne, 1998), which indicates an adequate fit of the model (Hu \& Bentler, 1999). The NFI value of 0.90 also indicates a reasonable fit.

From all of the values obtained above, the structural model shows an acceptable fit.

Table 1. Tests of model fit

\begin{tabular}{lll}
\hline Indicator & Recommended value & Value \\
\hline$x^{2}$ & $\mathrm{P} \leq 0.05$ & $\mathrm{P}=0.000$ \\
RMSEA & $\leq 0.08$ & 0.05 \\
GFI & $\geq 0.90$ & 0.90 \\
AGFI & $\geq 0.90$ & 0.87 \\
NFI & $\geq 0.90$ & 0.90 \\
IFI & $\geq 0.90$ & 0.96 \\
CFI & $\geq 0.90$ & 0.96 \\
Normed $x^{2}$ & $1-2$ & 1.62 \\
\hline
\end{tabular}

To test the hypotheses, a structural equation model (SEM) was used (Hair, Anderson, Tatham, \& Black, 1998). All measurements of the equations were statistically significant at a significance level of 0.05 , and the measures of reliability and variance extracted from the constructs were all significant (Table 2). The estimated standardized regression coefficients are shown (all $\mathrm{t}$ values exceed the reference values of 1.96 for a significance level of $0.05)$.

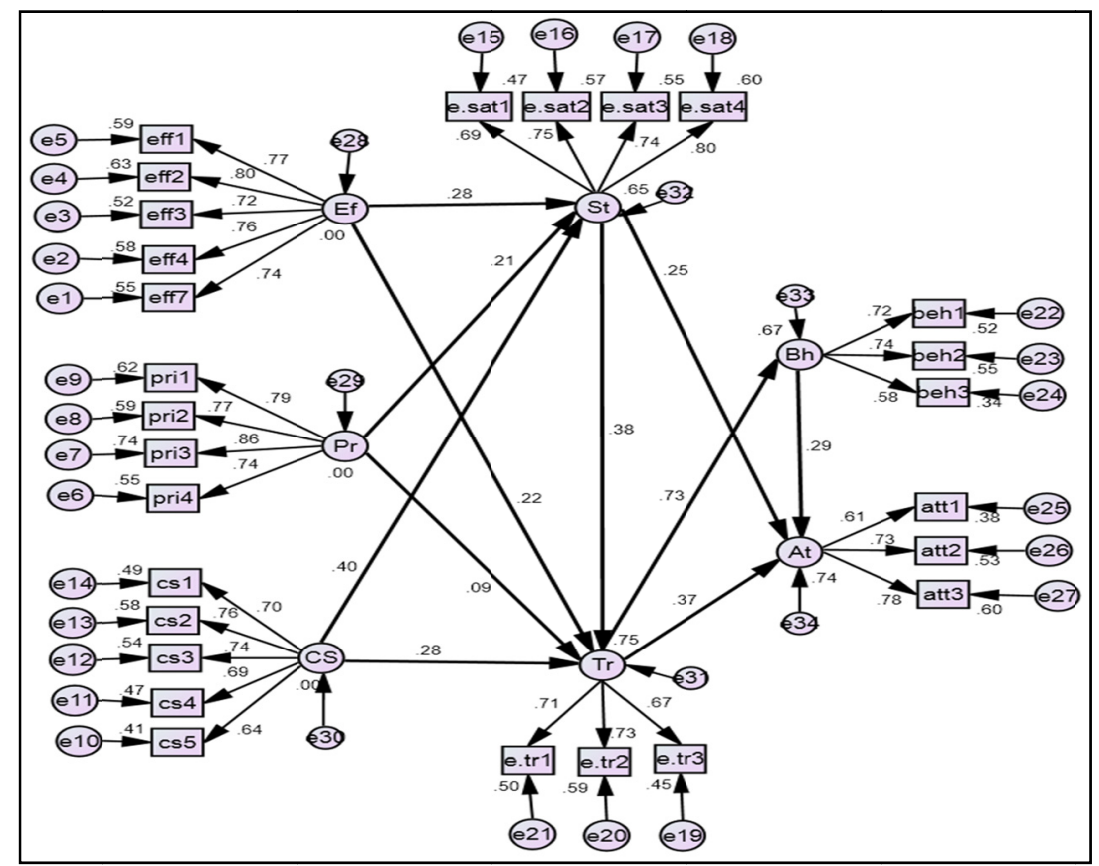

Figure 2. AMOS model 
Table 2. Structural parameters

\begin{tabular}{|c|c|c|c|c|c|c|c|}
\hline Causal Path & & & $\begin{array}{l}\text { Estimated } \\
\text { coefficient }\end{array}$ & S.E. & $\mathrm{P}$ & $\begin{array}{l}\text { Standardized estimated } \\
\text { coefficient }\end{array}$ & Hypothesis \\
\hline Efficiency & $-->$ & Satisfaction & 0.22 & .10 & .03 & 0.40 & Not supported \\
\hline Privacy & $-->$ & Satisfaction & 0.16 & .10 & .10 & 0.21 & Not supported \\
\hline Customer Service & $-->$ & Satisfaction & 0.39 & .08 & $* * *$ & 0.40 & Supported \\
\hline Efficiency & $-->$ & Trust & 0.19 & .12 & .13 & 0.22 & Not supported \\
\hline Privacy & $-->$ & Trust & 0.08 & .11 & .49 & 0.09 & Not Supported \\
\hline Customer Service & $-->$ & Trust & 0.29 & .10 & .00 & 0.28 & Supported \\
\hline Satisfaction & $-->$ & Trust & 0.41 & .11 & $* * *$ & 0.38 & Supported \\
\hline Satisfaction & $-->$ & Attitudinal & 0.23 & .13 & .07 & 0.25 & Not supported \\
\hline Trust & $-->$ & Behavioral & 0.74 & .08 & $* * *$ & 0.73 & Supported \\
\hline Trust & $-->$ & Attitudinal & 0.30 & .11 & .01 & 0.37 & Supported \\
\hline Behavioral & $->$ & Attitudinal & 0.24 & .11 & .04 & 0.29 & Supported \\
\hline
\end{tabular}

Note. S.E.: Standard Error. P: p-value, three stars, “***”, means the p-value is less than 0.001 .

\section{Discussion, Limitations and Future Research}

The aim of this study was to discover the extent to which the attributes of e-service quality perceived by the customers of online stores led to a disposition to be a loyal customer, in a new geographical context (Jordan). Using a student sample from the University of Jordan $(\mathrm{N}=302)$, this study found that loyalty (i.e., behavioral and attitudinal loyalty) depends on the customer's opinion of the quality of service for the online shopping, with efficiency, privacy and customer service being the main explanatory factors fore-SQ. Furthermore, satisfaction was found to mediate the relationship between e-SQ and behavioral and attitudinal loyalty.

According to the results, and in contrast to the previous findings (e.g., Gera, 2013; Shahabuddin, 2014; Zeglat et al., 2016), efficiency and privacy were found to have no impact on e-satisfaction. However, significant links were found between customer service and e-satisfaction and trust, and here the results were similar to those of other studies (e.g., Al-Nasser et al., 2013; Kao \& Lin, 2016; Shahabuddin, 2014; Swaid \& Wigand, 2009). Consequently, customer service has a positive influence one-satisfaction and trust, while content and ease of use has no impact. This is because the respondents in this study were young people and were students, so they possess great skills for finding the information they want and navigating through the information easily; this is consistent with Hansen \& Jonsson (2013).

Furthermore, regarding the link between trust, satisfaction, and loyalty (attitudinal and behavioral), positive and significant relationships were found between e-satisfaction and e-trust, and between e-trust and e-loyalty. Additionally, while the link between these variables has been established before (Chen et al., 2013; Cristóbal et al., 2007; Kassim \& Abdullah, 2010; Swaid \& Wigand, 2009; Prougestaporn, Visansakon, \& Saowapakpongchai, 2015; Wali \& Opara, 2012), this finding can be distinguished because it establishes a link between trust and two different types of loyalty (attitudinal and behavioral). Furthermore, the literature appears to use different dimensions of loyalty when measuring it, taking it as a single construct (Cristóbal et al., 2007; Wali \& Opara, 2012), or in terms of intent contribution and word of mouth (Kassim \& Abdullah, 2010), or in terms of preference loyalty, price tolerance or complaint behavior (Swaid \& Wigand, 2009). As a result, this study contributes to the literature by examining and finding significant links between e-SQ and behavioral and attitudinal loyalty. This distinction is important and means that for a firm to get a competitive advantage it should take into consideration the causal relationships between e-satisfaction, e-trust, behavioral loyalty and attitudinal loyalty, without ignoring any of these constructs.

To conclude, this study found customer service to be the most important factor in customer trust. Consequently, to obtain the satisfaction and trust of customers the online stores should take into consideration factors such as after-sales support, by showing a sincere interest in solving any problems encountered by customers and providing a quick response to customer needs (Parasuraman et al., 2005; Wolfinbarger \& Gilly, 2003). Moreover, in this research we can confirm that there are positive relationships between the main constructs of the measurement model: e-satisfaction, e-trust and two types of e-loyalty (behavioral and attitudinal). E-trust is an antecedent of e-satisfaction, and consumers will be satisfied if the website has given them reasons for trust. The results of this research confirm those obtained by Singh \& Sirdeshmukh (2000), who proposed that consumers' trust evaluations have a direct influence on their post-purchase satisfaction. 
Additionally, there are several implications for managers in the results of this research. Online stores must work on their customer care strategies to ensure that their products and services are delivered at the promised time or as quickly as possible. Also, it is important to help customers if problems arise, and to offer excellent after-sales support, because service failures and product recalls often lead to customers complaining, switching providers, or even taking revenge (Obeidat, 2014).

However, as with all studies dealing with human behavior, there are a number of limitations to this research. The first is that only one established online retailer (i.e., amazon.com) was analyzed. Further investigation of several companies is recommended. Furthermore, experimental web sites designs are often recommended in this context to allow researchers to examine more closely whether the manipulation of the e-SQ elements would lead to an enhanced sense of trust and loyalty. Additionally, the model was validated in this study with reference to the measurement of e-service quality in the case of a business to customer (B2C) relationship; other studies could attempt to validate this model with a business to business (B2B) relationship. Finally, this model could also be adapted to evaluate the perceived quality of services through social media platforms.

\section{References}

Águila, A. R., Meléndez, A. P., \& Al-dweeri, R. M. (2013). The influence of electronic service quality on loyalty in postal services: The mediating role of satisfaction. Total Quality Management and Business Excellence, 24(9), 1111-1123. https://doi.org/10.1080/14783363.2013.807681

Ahmad, S. (2002). Service failures and customer defection: A closer look at online shopping experiences. Managing Service Quality, 12(1), 19-29. https://doi.org/10.1108/09604520210415362

Al Dmour, H., Alshurideh, M., \& Shishan, F. (2014). The influence of mobile application quality and attributes on the continuance intention of mobile shopping. Life Science Journal, 11(10), 172-181.

Aladwani, A. M. (2002). The development of two tools for measuring the easiness and usefulness of transactional Web sites. European Journal of Information Systems, 11(3), 223-231. https://doi.org/10.1057/palgrave.ejis.3000432

Aladwani, A. M. (2006). An empirical test of the link between web site quality and forward enterprise integration with web consumers. Business Process Management Journal, 12(2), 178-190. https://doi.org/10.1108/14637150610657521

Al-Nasser, M., Yusoff, R. Z., Islam, R., \& AlNasser, A. (2013). E-service quality and its effect on consumers' perceptions trust. American Journal of Economics and Business Administration, 5(2), 47. https://doi.org/10.3844/ajebasp.2013.47.55

Anderson, R. E., \& Srinivasan, S. S. (2003). E-satisfaction and e-loyalty: A contingency framework. Psychology and Marketing, 20(2), 99-121. https://doi.org/10.1002/mar.10063

Azam, A., Qiang, F., \& Abdullah, M. I. (2012). Satisfaction in business-to-consumer electronic commerce. The Business and Management Review, 3(1), 18-26.

Bagozzi, R. P., Yi, Y., \& Nassen, K. D. (1998). Representation of measurement error in marketing variables: Review of approaches and extension to three-facet designs. Journal of Econometrics, 89(1), 393-421. https://doi.org/10.1016/S0304-4076(98)00068-2

Barnes, S., \& Vidgen, R. (2002). An integrative approach to the assessment of e-commerce quality. Journal of Electronic Commerce Research, 3(3), 114-127.

Bauer, H., Falk, T., \& Hammerschmidt, M. (2006). eTransQual: A transaction process-based approach for capturing service quality in online shopping. Journal of Business Research, 59, 866-875. https://doi.org/10.1016/j.jbusres.2006.01.021

Beneke, J., Acton, A., Richardson, D., \& White, F. (2011). E-service quality: An investigation of its key dimensions and the discriminatory power in the residential property sector. Acta Commercii, 11(1), 75-87.

Browne, M. W., \& Cudeck, R. (1993). Alternative ways of assessing model fit. In K. A. Bollen \& J. S. Long (Eds.), Testing structural equation models (pp. 136-162). Beverly Hills, CA: Sage.

Byrne, B. M. (2001). Structural equation modeling with Amos: Basic concepts, applications and programming. New Jersy: Lawrence Erlbaum Associates.

Chen, M. H., Tsai, K. M., Hsu, Y. C., \& Lee, K. Y. (2013). E-service quality impact on online customer's perceived value and loyalty. China-USA Business Review, 12(5). 
Chu, K. (2009). The construction model of customer trust, perceived value and customer loyalty. The Journal of American Academy of Business, 14(2), 98-103.

Collier, J. E., \& Bienstock, C. C. (2006). Measuring service quality in e-retailing. Journal of service research, 8(3), 260-275. https://doi.org/10.1177/1094670505278867

Cox, J., \& Dale B. (2001). Service quality and e-commerce: An exploratory analysis. Managing Service Quality, 11(2), 121-132. https://doi.org/10.1108/09604520110387257

Cox, J., \& Dale B. (2002). Key quality factors in web site design and use: An examination. International Journal of Quality and Reliability Management, 17(7), 862-888. https://doi.org/10.1108/02656710210434784

Cristóbal, E., Flavián, C., \& Guinalíu, M. (2007). Perceived e-service quality (PeSQ): Measurement validation and effects on consumer satisfaction and web site loyalty. Managing Service Quality, 17(3), 317-340. https://doi.org/10.1108/09604520710744326

Cronin, J. J., \& Taylor, S. A. (1992). Measuring service quality: A re-examination and extension. Journal of Marketing, 56(3), 55-68. https://doi.org/10.2307/1252296

Cronin, J. J., Brady, M. K., \& Hult, G. T. M. (2000). Assessing the effects of quality, value, and customer satisfaction on consumer behavioral intentions in service environments. Journal of retailing, 76(2), 193-218. https://doi.org/10.1016/S0022-4359(00)00028-2

Cyr, D., Kindra, G., \& Dash, S. (2008). Web site design, trust, satisfaction and e-loyalty: The Indian experience. Online Information Review, 32(6), 773-790. https://doi.org/10.1108/14684520810923935

Dunn, G., Baloglu, S., Brewer, P., \& Qu, H. (2009). Consumer e-loyalty to online travel intermediaries. Journal of Quality Assurance in Hospitality and Tourism, 10(1), 1-22. https://doi.org/10.1080/15280080802713751

Fassnacht, M., \& Koese, I. (2006). Quality of electronic services: Conceptualizing and testing a hierarchical model. Journal of Service Research, 9(1), 19-38. https://doi.org/10.1177/1094670506289531

Flavián, C., Guinalíu, M., \& Gurrea, R. (2006). The role played by perceived usability, satisfaction and consumer trust on website loyalty. Information and Management, 43(1), 1-14. https://doi.org/10.1016/j.im.2005.01.002

Gefen, D., Karahanna, E., \& Straub, D. W. (2003). Trust and TAM in online shopping: An integrated model. MIS Quarterly, 27(1), 51-90.

Gommans, M., Krishnan, K. S., \& Scheffold, K. B. (2001). From brand loyalty to e-loyalty: A conceptual framework. Journal of Economic and Social Research, 3(1), 43-58.

Gounaris, S., \& Dimitriadis, S. (2003). Assessing service quality on the web: Evidence from business-to-consumer portals. Journal of Services Marketing, 17(5), 529-548. https://doi.org/10.1108/08876040310486302

Gounaris, S., Dimitriadis, S., \& Stathakopoulos, V. (2010). An examination of the effects of service quality and satisfaction on customers' behavioral intentions in e-shopping. Journal of Services Marketing, 24(2), 142-156. https://doi.org/10.1108/08876041011031118

Gronholdt, L., Martensen, A., \& Kristensen, K. (2000). The relationship between customer satisfaction and loyalty: Cross-industry differences. Total Quality Management, 11(4-6), 509-514. https://doi.org/10.1080/09544120050007823

Grönroos, C., Heinonen, F., Isoniemi, K., \& Lindholm, M. (2000). The NetOffer model: A case example from the virtual marketplace. Management Decision, 38(4), 243-252. https://doi.org/10.1108/00251740010326252

Gummerus, J., Liljander, V., Pura, M., \& Van Riel, A. (2004). Customer loyalty to content-based websites: The case of an online health-care service. Journal of Services Marketing, 18(3), 175-186. https://doi.org/10.1108/08876040410536486

Hair, J. F., Anderson, R. E., Tatham, R. L., \& Black, W. C. (1998). Multivariate data analysis with readings. Englewood Cliffs, NJ: Prentice Hall.

Hansen, E., \& Jonsson, E. (2013). E-loyalty in fashion e-commerce: an investigation in how to create e-loyalty. Master Thesis, Linnaeus University, June.

Herington, C., \& Weaven, S. (2007). Can banks improve customer relationships with high quality online services? Managing Service Quality, 17(4), 404-417. https://doi.org/10.1108/09604520710760544 
Ho, C. I., \& Lee, P. L. (2015). Are blogs still effective to maintain customer relationships? An empirical study on the travel industry. Journal of Hospitality and Tourism Technology, 6(1). 5-25. https://doi.org/10.1108/JHTT-01-2015-0005

Howard, P. E. N., Rainie, L., \& Jones, S. (2001). Days and nights on the internet: The impact of a diffusing technology. American Behavioral Scientist, 45(3), 383-404. https://doi.org/10.1177/00027640121957259

Hsu, J., \& Hsu, C. (2008). The relationships between service quality and customer satisfaction in a leading Chinese Web 2.0 company. The Business Review, 11(1), 84-90.

Hu, H. H., Kandampully, J., \& Juwaheer, T. D. (2009). Relationships and impacts of service quality, perceived value, customer satisfaction, and image: An empirical study. The Service Industries Journal, 29(2), 111-125. https://doi.org/10.1080/02642060802292932

Hu, L., \& Bentler, P. (1999). Cutoff criteria for fit indexes in covariance structure analysis: Conventional criteria versus new alternatives. Structural Equation Modeling, 6(1), 1-55. https://doi.org/10.1080/10705519909540118

Ibrahim, E. E., Joseph, M., \& Ibeh, K. (2006). Customers' perception of electronic service delivery in the UK retail banking sector. International Journal of Bank Marketing, 24(7), 475-493. https://doi.org/10.1108/02652320610712094

Jöreskog, K. G., \& Sörbom, D. (1989). LISREL 7: A guide to the program and applications. Spss.

Kassim, N., \& Asiah Abdullah, N. (2010). The effect of perceived service quality dimensions on customer satisfaction, trust, and loyalty in e-commerce settings: A cross cultural analysis. Asia Pacific Journal of Marketing and Logistics, 22(3), 351-371. https://doi.org/10.1108/13555851011062269

Kim, J., Jin, B., \& Swinney, J. L. (2009). The role of etail quality, e-satisfaction and e-trust in online loyalty development process. Journal of Retailing and Consumer Services, 16(4), 239-247. https://doi.org/10.1016/j.jretconser.2008.11.019

Kim, S., \& Stoel, L. (2004). Dimensional hierarchy of retail website quality. Information and Management, 41(5), 619-633. https://doi.org/10.1016/j.im.2003.07.002

Kline, R. B. (1998). Principles and Practice of Structural Equation Modeling. New York: The Guilford Press.

Kristensen, K., Martensen, A., \& Gronholdt, L. (2000). Customer satisfaction measurement at Post Denmark: Results of application of the European Customer Satisfaction Index Methodology. Total Quality Management, 11(7), 1007-1015. https://doi.org/10.1080/09544120050135533

Lee, G., \& Lin, H. (2005). Customer perceptions of e-service quality in online shopping. International Journal of Retail and Distribution Management, 33(2), 161-176. https://doi.org/10.1108/09590550510581485

Li, Y. N., Tan, C. K., \& Xie, M. (2002). Measuring web-based service quality. Total Quality Management, 13(5), 685-700. https://doi.org/10.1080/0954412022000002072

Lien, C. H., Wen, M. J., \& Wu, C. C. (2011). Investigating the relationships among e-service quality, perceived value, satisfaction, and behavioral intentions in Taiwanese online shopping. Asia Pacific Management Review, 16(3), 211-223.

Loiacono, E., Watson, R. T., \& Goodhue, D. (2002). WebQual: A web site quality instrument. Marketing Theory and Applications, 13, 432-438.

Loiacono, E., Watson, R. T., \& Goodhue, D. (2007). WebQual: An instrument for consumer evaluation of web sites. International Journal of Electronic Commerce, 11(3), 51-87. https://doi.org/10.2753/JEC1086-4415110302

Lynch, P. D., Kent, R. J., \& Srinivasan, S. S. (2001). The global internet shopper: Evidence from shopping tasks in twelve countries. Journal of Advertising Research, 41(3), 15-23. https://doi.org/10.2501/JAR-41-3-15-23

Malhotra, A., \& Segars, A. H. (2005). Investigating wireless web adoption patterns in the U.S. Communications of the ACM, 48(10), 105-117. https://doi.org/10.1145/1089107.1089113

Marimon, F., Petnji Yaya, L. H., \& Casadesus Fa, M. (2012). Impact of e-quality and service recovery on loyalty: A study of e-banking in Spain. Total Quality Management and Business Excellence. https://doi.org/10.1080/14783363.2011.637795

McKinney, V., Yoon, K., \& Zahedi, F. M. (2002). The measurement of web-customer satisfaction: An expectation and disconfirmation approach. Information System Research, 13(3), 296-315. 
https://doi.org/10.1287/isre.13.3.296.76

O’Neill, M., Wright, C., \& Fitz, F. (2001).Quality evaluation in online service environments: an application of the importance performance measurement technique. Managing Service Quality, 11(6), 402-417. https://doi.org/10.1108/EUM0000000006519

Obeidat, Z. (2014). Beware the Fury of the Digital Age Consumer: Online Consumer Revenge: A Cognitive Appraisal Perspective (Doctoral dissertation, Durham University).

Pallant, J. (2001). SPSS Survival Manual: A Step by Step Guide to Data Analysis Using SPSS for Windows (Versions 10 and 11): SPSS Student Version 11.0 for Windows. Open University Press.

Parasuraman, A., Zeithaml, V., \& Berry, L. (1988). SERVQUAL: A multiple-item scale for measuring consumer perceptions of service quality. Journal of Retailing, 64(1), 12-40.

Parasuraman, A., Zeithaml, V., \& Malhotra, A. (2005). E-S-QUAL: A multiple-item scale for assessing electronic service quality. Journal of Service Research, 7(3), 213-233. https://doi.org/10.1177/1094670504271156

Pitta, D., Franzak, F., \& Fowler, D. (2006). A strategic approach to building online customer loyalty: Integrating customer profitability tiers. Journal of Consumer Marketing, 23(7), 421-429. https://doi.org/10.1108/07363760610712966

Pritchard, M., Havitz, M., \& Howard, D. (1999). Analyzing the commitment-loyalty link in service contexts. Journal of the Academy of Marketing Science, 27(3), 333-348. https://doi.org/10.1177/0092070399273004

Prougestaporn, P., Visansakon, T., \& Saowapakpongchai, K. (2015). Key success factors and evaluation criterias of e-learning websites for higher education.International Journal of Information and Education Technology, 5(3), 233. https://doi.org/10.7763/IJIET.2015.V5.507

Reichheld, F. F., \& Schefter, P. (2000). E-loyalty: Your secret weapon on the web. Harvard Business Review, 78(4), 105-113.

Ribbink, D., Van Riel, A., Liljander, V., \& Streukens, S. (2004). Comfort your online customer: Quality, trust, and loyalty on the internet. Managing Service Quality, 14(6), 446-456. https://doi.org/10.1108/09604520410569784

Rust, R. T. (2001). The rise of e-service. Journal of Service Research, 3(4), 283-295. https://doi.org/10.1177/109467050134001

Rust, R. T., \& Lemon, K. N. (2001). E-service and the consumer. International Journal of Electronic Commerce, 5(3), 83-99.

Ruyter, K., Wetzels, M., \& Kleijnen, M. (2001). Customer adoption of e-service: An experimental study. International Journal of Service Industry Management, 12(2), 184-207. https://doi.org/10.1108/09564230110387542

Santos, J. (2003). E-service quality: A model of virtual service quality dimensions. Managing Service Quality, 13(3), 233-246. https://doi.org/10.1108/09604520310476490

Shahabuddin, A. M. (2014). E-service quality for customer satisfaction measurement: a case study on Islami Bank Bangladesh Ltd. Global Disclosure of Economics and Business, 3, 32-39.

Shankar, V., Smith, A., \& Rangaswamy, A. (2003). Customer satisfaction and loyalty in online and offline environments. International Journal of Research in Marketing, 20, 153-175. https://doi.org/10.1016/S0167-8116(03)00016-8

Singh, J., \& Sirdeshmukh, D. (2000). Agency and trust mechanisms in consumer satisfaction and loyalty judgments. Journal of the Academy of Marketing Science, 28(1), 150-167. https://doi.org/10.1177/0092070300281014

Soltani, I., \& Gharbi J. E. (2008). Determinants and consequences of website perceived value. Journal of Internet Banking and Commerce, 13(1), 1-13.

Srinivasan, S. S., Anderson, R., \& Ponnavolu, K. (2002). Customer loyalty in e-commerce: An exploration of its antecedents and consequences. Journal of Retailing, 78(1), 41-50. https://doi.org/10.1016/S0022-4359(01)00065-3

Swaid, S. I., \& Wigand, R. T. (2009). Measuring the quality of e-service: Scale development and initial validation. Journal of Electronic Commerce Research, 10(1), 13-28. 
Szymanski, D. M., \& Hise, R. T. (2000). E-satisfaction: An initial examination. Journal of Retailing, 76(3), 309-322. https://doi.org/10.1016/S0022-4359(00)00035-X

Tsao, W. C., \& Tseng, Y. L. (2011).The impact of electronic-service quality on online shopping behaviour. Total Quality Management and Business Excellence, 22(9), 1007-1024. https://doi.org/10.1080/14783363.2011.593869

Van Riel, A., Liljander, V., \& Jurriens, P. (2001). Exploring consumer evaluations of e-services: A portal site. International Journal of Service Industry Management, 12(4), 359-377. https://doi.org/10.1108/09564230110405280

Van Riel, A., Semeijn, J., \& Janssen, W. (2003). E-service quality expectations: A case study. Total Quality Management and Business Excellence, 14(4), 437-450. https://doi.org/10.1080/1478336032000047255

Wali, A. F., \& Opara, B. C. (2012). E-Service quality experience and customer loyalty: an emphasis of the Nigeria airline operators. European Journal of Business and Social Sciences, 1(9), 118-125.

Wolfinbarger, M. F., \& Gilly, M. C. (2003). eTailQ: Dimensionalizing, measuring and predicting etail quality. Journal of Retailing, 79(3), 183-198. https://doi.org/10.1016/S0022-4359(03)00034-4

Woodside, A. G., Frey, L. L., \& Daly R. T. (1989). Linking service quality, customer satisfaction, and behaviour. Journal of Health Care Marketing, 9(4), 5-18.

Wu H. C. (2014). The effects of customer satisfaction, perceived value, corporate image and service quality on behavioral intentions in gaming establishments. Asia Pacific Journal of Marketing and Logistics, 26(4), 540-565. https://doi.org/10.1108/APJML-03-2014-0049

Wu, Y. L., Tao, Y. H., \& Yang, P. C. (2012). Learning from the past and present: measuring internet banking service quality. The Service Industries Journal, 32(3), 477-497. https://doi.org/10.1080/02642069.2010.529434

Yang, Z., \& Fang, X. (2004). Online service quality dimensions and their relationship with satisfaction: A content analysis of customer reviews of securities brokerage services. International Journal of Service Industry Management, 15(3), 302-326. https://doi.org/10.1108/09564230410540953

Yang, Z., Peterson, R. T., \& Cai, S. (2003). Service quality dimensions of internet retailing: An exploratory analysis. Journal of Service Marketing, 17(7), 685-700. https://doi.org/10.1108/08876040310501241

Yen, C. H., \& Lu, H. P. (2008). Effects of e-service quality on loyalty intention: An empirical study in online auction. Managing Service Quality, 18(2), 127-146. https://doi.org/10.1108/09604520810859193

Yoo, B., \& Donthu, N. (2001). Developing a scale to measure the perceived quality of an Internet shopping site (SITEQUAL). Quarterly Journal of Electronic Commerce, 2(1), 31-45.

Zeglat, D., Shrafat, F., \& Al-Smadi, Z. (2016). The Impact of the E-Service Quality (E-SQ) of Online Databases on Users' Behavioural Intentions: A Perspective of Postgraduate Students. International Review of Management and Marketing, 6(1).

Zeithaml, V., Parasuraman, A., \& Malhotra, A. (2002). Service quality delivery through web sites: A critical review of extant knowledge. Academy of Marketing Science Journal, 30(4), 362-375. https://doi.org/10.1177/009207002236911

Zhang, P., \& Dran, G. (2000). Satisfiers and dissatisfiers: A two-factor model for website design and evaluation. Journal of the American Society for Information Science, 51(14), 1253-1268. https://doi.org/10.1002/1097-4571(2000)9999:9999\%3C::AID-ASI1039\%3E3.0.CO;2-O

\section{Copyrights}

Copyright for this article is retained by the author, with first publication rights granted to the journal.

This is an open-access article distributed under the terms and conditions of the Creative Commons Attribution license (http://creativecommons.org/licenses/by/4.0/). 